\title{
Experiência de Formação Superior no Grupo PET INTERCULTURAL
}

\author{
Lucirene Bento Barbosa ${ }^{1}$
}

DOI: http://dx.doi.org/10.20435/tellus.v18i35.464

Meu nome é Lucirene Bento Barbosa, sou do povo indígena macuxi, da comunidade Pium, região Tabaio Município de Alto Alegre, Roraima. Tenho duas filhas Laura com 18 anos e Eduarda com 16 anos, bem, engravidei aos 17 anos e depois aos 19 anos e comecei trabalhar em casa de família para poder sustentar minhas filhas. Morei com uma família por 10 anos e atualmente somos amigos.

Quando ainda morava nesta casa decidi estudar, porque estava cansada de tudo, mais ficava me perguntando: daqui vou trabalhar onde? em outra casa de família? Então foi aí que conversei com meus patrões e comuniquei que ia estudar, e eles me apoiaram. Tinha parado de estudar na 5 a série e comecei a estudar no SESI fazendo o provão, pois facilitava o estudo pela noite. Terminei o ensino fundamental no SESI e depois o médio na Escola Estadual Hildebrando Bittencourt, fazendo o EJA, na cidade de Boa Vista.. Quando estava terminando o 3 ano me inscrevi no vestibular indígena da UFRR e passei.

Quando fui entregar meus documentos descobri que não poderia fazer minha matrícula, pois não tinha meu histórico de conclusão do ensino médio. Voltei para casa chorando, chegando em casa meu patrão perguntou porque estava chorando e expliquei a minha situação e ele falou vamos: ter que agir. Ele é advogado e entrou com uma ação judicial para que a UFRR esperasse eu terminar o ensino médio e aceitar minha matrícula e ganhamos a causa e hoje estou eu aqui fazendo este relato.

A Universidade me trouxe várias oportunidades, o Instituto Insikiran é uma unidade acadêmica que veio para nortear o estudante indígena, para somar nos seus conhecimentos para a vida profissional. Nesse período que estou na uni-

${ }^{1}$ Universidade Federal de Roraima (UFRR), Campus Paricarana, Roraima, Brasil.

Tellus, Campo Grande, MS, ano 18, n. 35, p. 179-180, jan./abr. 2018 
versidade já viajei para Curitiba, participei da 22a Conferencia Mundial de Saúde, foi uma experiência única. Participei também de várias atividades como eventos na universidade, movimentos, reuniões, etc. Comecei a participar em 2015 do Programa de Educação Tutorial: PET INTERCULTURAL. Apareceram assim mais oportunidades de estudo, como aprender a fazer leituras, fichamentos e a ser uma pesquisadora, pois uma coisa é ser aluno outra é ser um aluno pesquisador.

O PET INTERCULTURAL estimula você a estudar e a adquirir novos conhecimentos. Os encontros que foram realizados com outros colegas, seja estudantes de outros cursos ou projetos foi importante para mi, como encontros com estudantes do projeto Observatório da Educação Indígena/ OBEDUC, assim como participar do grupo de pesquisa CNPq, junto do professor tutor do PET. Foi uma experiência importante em minha vida, pois permitiu conhecer os trabalhos de alunos ja formados que fazem pesquisa na pós-graduação. Descobri assim, estudando e trocando ideias que a formação superior pode ser muito gratificante.

Tudo tem sido importante para mim, uma experiência única. Ressalto o fato que me senti vivendo uma experiência importante, pois me senti passando de objeto pesquisado para ser uma pesquisadora, como aluna indígena e isso abriu minha mente e certamente será algo importante para minha vida futura, como profissional indígena.

Obrigada.

\section{Sobre a autora:}

Lucirene Bento Barbosa: Estudante do Curso Gestão em Saúde Coletiva Indígena, Instituto Insikiran de Formação Superior Indígena da Universidade Federal de Roraima. Bolsista PET INTERCULTURAL. Tutoria do Prof. Maxim Repetto. E-mail: barbosalucys2@gmail.com

Recebido em 31 de março de 2017

Aprovado para publicação em 15 de maio de 2017 